\title{
Absolute and difference limen in visual perception as a function of the duration of stimulus pulse
}

\author{
O. P. TAYAL \\ Humanities Department, Indian Institute of Technology, I.I.T., Kanpur-16, India
}

\begin{abstract}
This paper criticizes the current approach in psychophysics in interpreting the absolute or difference limen indices under the reciprocity relation for small values of $t$ and under the constancy relation for large values of $t$. It reiterates Tayal's (1965) model, and demonstrates, by examining its empirical validity against reported data, that the phenomenon can be meaningfully interpreted under a single set of principles for the entire range of $t$ values including the outcomes in the so-called critical duration. It demonstrates that the two apparently different mathematical relations do not signify any dichotomy at the level of receptor mechanism or functional processing; rather, they approximate a better articulated function which is capable of characterizing the phenomenon for the entire range of $t$ values inclusive of the inexplicable critical duration " $t_{c}$ "
\end{abstract}

When the retinal area of stimulation is kept constant, the function in which threshold luminance varies with duration is defined in terms of the reciprocity relation $\mathrm{I} \cdot \mathrm{t}=\mathrm{C}$ for small durations up to 100 msec (Blondel \& Rey, 1911; Davy, 1952; Graham \& Margaria, 1935; Karn, 1936; Long, 1951; Rouse, 1952), and by the relation $I=C$ for larger values of t (Graham \& Margaria, 1935; Karn, 1936; Mote, 1967). Similar trends are discovered in the relation between difference limen (DL) and the durations of comparison stimulus pulse (Graham \& Kemp, 1938; Herrick, 1956).

The two mathematical relations to which empirical data conform at different ranges of values of $t$ obviously look so different that no unity between them can be envisaged. This has given rise to assumptions which ascribe the two apparently different outcomes to the shifting of receptor functioning from the rod cells to the cone cells (Graham \& Kemp, 1938; Graham \& Margaria, 1935) or to some failure of the summation process beyond some critical duration " $t_{c}$ " (Mote, 1967). Such explanations, however, have little theoretical validity. It is borne out that the density function of impulses from single neurons follow a similar pattern with $t$ as variant (Hartline, 1934, 1938).

The existing formulations suffer from another weakness; they are incapable of articulating the relation between the relevant variables in the intermediate range of $t$ values. The functional character in this range is assumed to undergo some rapid transition from one set of principles of processing to another set of principles of processing. $t$ in this part is simply described as some inexplicable critical duration, " $t_{c}$."
This paper demonstrates that the apparently different reciprocity and constancy relations, one for small values of $t$ and the other for large values of $t$, when interpreted correctly, do not indicate any change or shift in functional processing at the receptor level. The two empirically defined mathematical functions do not seem to describe the phenomenon truly. Rather, they represent simplified versions, as near approximations, of a more comprehensively defined function which is capable of interpreting it more meaningfully for the entire range of $t$ values.

This paper also demonstrates that it is not at all necessary to subscribe to the hypothesis of some inexplicable critical duration in the intermediate range of $t$ values. The outcomes in this range seem to be as much governed by the same set of principles as the outcomes anywhere else on the $t$ contnuum.

\section{THEORETICAL CONSTRUCT}

Tayal (1965), in an earlier publication, proposed that the intervening neural excitation might be conceived of as involving two opposing processes going on simultaneously: one, a positive process leading to an increment, and the other, a negative process leading to a decrement. The increment in neural excitation per unit of time is envisaged as being proportional to $\mathrm{X}^{\mathrm{n}}$, where $\mathrm{X}$ is the intensity of the stimulus input and $n$ is some constant power of $X$, and the decrement per unit of time is conceived of as being proportional to the level of accumulated neural excitation at time $t$. The author examined the theoretical validity of his propositions for diverse psychophysical phenomena in his earlier publication. This paper reexamines the same model to demonstrate that the 
interpretations of absolute and difference limen with $t$ as variant need a radical revision.

Under the proposed model, when $\mathrm{X}$ is the intensity of some stimulus input and $Y$ is the level of neural excitation at any time $t$ after the presentation of that stimulus,

$$
d y=\left(K \cdot X^{n} \cdot d t\right)-(r \cdot Y \cdot d t),
$$

where $r$ and $K$ are proportionality constants.

Integrating Function 1 and putting $\mathrm{Y}=\mathrm{Y}_{\mathrm{o}}$ (the initial level of stimulation) when $t=0$, we have

$$
Y=\frac{K}{r} X^{n} \cdot\left(1-\frac{1}{e^{r t}}\right)+\frac{Y_{o}}{e^{r t}} .
$$

\section{FUNCTIONAL RELATIONS FOR ABSOLUTE AND DIFFERENCE LIMEN}

Let $\mathrm{X}$ be the intensity of current stimulation which is assumed to be present in the visual field for a sufficiently long duration, and let $Y_{1}$ be the level of neural excitation before the onset of the comparison stimulus pulse. Then, under the proposed model,

$$
Y_{1}=\frac{K}{r} \cdot X^{n}
$$

since ert is fairly large.

Let $\mathrm{X}+\mathrm{DX}$ be the intensity of the comparison stimulus pulse which is presented for a duration $t$ when the initial level of excitation is $Y_{1}$, and let $Y_{2}$ be the level of neural excitation at time $t$. Then, from Equation 2,

$$
Y_{2}=\frac{K}{r} \cdot(X+D X)^{n} \cdot\left(1-\frac{1}{e^{r t}}\right)+\frac{Y_{t}}{e^{r t}} .
$$

Let us further assume that for the awareness of a difference between $Y_{1}$ and $Y_{2}$ at the experiential level, the difference between them exceeds some critical minimum level, $C$. For just noticeable difference between $\mathrm{X}$ and $\mathrm{X}+\mathrm{DX}$, therefore,

$$
Y_{2}-Y_{1}=C \text {, }
$$

or that

$$
\frac{K}{r} \cdot\left\{(X+D X)^{n} \cdot\left(1-\frac{1}{e^{r t}}\right)-X^{n} \cdot\left(1-\frac{1}{e^{r t}}\right)\right\}=C .
$$

Relation 6, in simplified form, can be expressed as

$$
(X+D X)^{n}-X^{n}=C^{\prime} \cdot \frac{e^{r t}}{e^{r t}-1},
$$

where $C^{\prime}$ is a newly defined constant.

Equation 7 defines the relation between $t$ and $D X$ for difference limen under those experimental conditions in which the comparison stimulus pulse is superimposed on part of the existing visual field for a variable duration $t$.

The absolute limen is simply a particular case of difference thresholds where the awareness of the presence of some stimulus, in fact, refers to its comparison with no stimulation. When $\mathrm{X}=0$, Equation 7 reduces to

$$
D X^{n}=C^{\prime} \cdot \frac{e^{r t}}{e^{r t}-1}
$$

\section{RECIPROCITY AND CONSTANCY RELATIONS UNDER THE FORMULATIONS}

Expressing $\left.\mathrm{e}^{\mathrm{rt}} / \mathrm{e}^{\mathrm{rt}}-1\right)$ as $1 /\left(1-\mathrm{e}^{-\mathrm{rt}}\right)$ and expanding the exponential function, we find that the expression approximates $1 / \mathrm{rt}$ when $\mathrm{rt}$ is small. To illustrate, when $\mathrm{rt}=.125$, the difference between the more rigorously defined function and $1 / \mathrm{rt}$ is of the order of only about $5.4 \%$. In fitting either of the two functions to observed data within the domain of values of $\mathrm{rt}<.125$ or even $<.25$, when best fitting values of the constants are chosen, the discrepancy in the error components between the two functions will be almost negligible; one function, therefore, could very well substitute for the other.

When $1 / \mathrm{rt}$ is substituted for the expression ert/ (ert -1 ) in Equation 8 , and $n$ the power of $\mathrm{X}$ is assumed to be equal to unity, the relation fully corresponds with the reciprocity relation defined for absolute limen. There is no restriction in the choice of the values of the parametric constants $r$; and $n$, Equation 8, therefore, can always be made to correspond with the reciprocity relation defined for small values of $t$. The proposed function is rather more general and would obviously show a better fit with observed data than the reciprocity relation for the phenomenon.

Similarly, for difference limen, when $1 / \mathrm{rt}$ is substituted for ert/(ert -1$)$ in Equation 7 , and $n$, the power index, is assumed to be equal to unity, the relation fully corresponds with the reciprocity relation for small values of $t$. Even when $n \neq 1$ but $X$ is fairly large in relation to DX, such that the second and higher order terms in the expansion of $(1+\mathrm{DX} / \mathrm{X})^{\mathrm{n}}$ are ignored, Equation 7 will still conform to the reciprocity relation for small values of rt. Hence, assuming that the true phenomenon is articulated through the more rigorously defined function as proposed here, observed data will not materially deviate from the reciprocity relation both for absolute and difference limen in the range of small values of $t$. 
When $\mathrm{rt}$ is large, ert/(ert -1$)$ approximates unity; viz, when $\mathrm{rt}=3$, the value of this function exceeds 1 by about $5 \%$ only. Variation in the range of $\mathrm{rt}$ values $>3$ will produce negligible difference in the estimated values of DX, in both Equations 7 and 8 defined for difference and absolute limen. The proposed relations, therefore, conform with the constancy relation for large values of $t$ as well.

The proposed formulations are thus capable of explaining the outcomes both in the small and large values of $t$ under a single set of principles.

\section{CONCEPT OF CRITICAL DURATION}

The outcomes in the intermediate range of $t$ values are not accounted for either by the reciprocity relation or the constancy relation. Since no suitable mathematical function could be defined to interpret the outcomes in this range, it is described as a critical duration " $t_{c}$ " at which the character of the receptor mechanism is believed to undergo some functional changes in its transition from the reciprocity relation to the constancy relation.

The inexplicable changes in the intermediary range of $t$ values are, however, duly predicted under the proposed function. It clearly brings out that the rate of change in $\mathrm{X}$ or DX with $\mathrm{t}$ does not conform either to the reciprocity relation or to the constancy relation for values of $r \cdot t$ between .25 and 2.5. The concept of critical duration seems to have primarily arisen because too much faith is placed on the two empirically defined functions which do not truly characterize the phenomenon. It seems that these functions may be representing near approximations in different ranges of $t$ values of a better articulated function capable of accounting for the outcomes for the entire range of $t$ values under the same set of principles. The proposed formulations thus demonstrate that the concept of critical duration is unwarranted and seems to be misconceived.

\section{HECHT'S FORMULATIONS}

Hecht (1934) has tried to explain the apparently different outcomes for small and large values of $t$ under his own hypothetical photochemical model. He has, however, not been very successful in this; the reasoning which he employs is rather faulty and mathematically unsound.

Hecht (1934) presumes that the light impinging on the retina acts on some light-sensitive substance, $\mathrm{S}$, so as to break it down into primary photoproducts, $\mathbf{P}+\mathbf{A}$, etc. The rate of change in the concentration of photoproducts was presumed to depend on the luminance $L$ of the stimulus input and on the concentration $(a-x)$ of $S$, where " $a$ " is the total concentration of the photochemical substance in the recep- tor cell prior to the onset of stimulus and " $x$ " is the quantity which is catabolized by the light energy impinging on that cell in time t. Assuming that there is no reformation of $P$ back into $S$ as a result of some reverse anabolic process, the velocity of chemical reaction at time $t$ after the onset of stimulus is defined as

$$
\frac{d x}{d t}=K_{1} \cdot t \cdot(a-x)^{m},
$$

where $K_{1}$ is a velocity constant and $m$ denotes the order of reaction.

If, now, a reformation of $P$ back into $S$ is assumed, the rate of reformation will depend on the concentration of $x$, the catabolized product. Thus, a back reaction will take place with a rate $\mathrm{dx} / \mathrm{dt}=\mathrm{k}_{2} \cdot \mathrm{x}^{\mathrm{n}}$, where $\mathrm{k}_{2}$ is another velocity constant and $n$ another constant denoting the order of reactions involved in the chemical reformation. Hecht, therefore, defines the velocity of chemical reaction at any time $t$ after the onset of the stimulus as

$$
\frac{d x}{d t}=k \cdot L \cdot(a-x)^{m}-k_{2} \cdot x^{n},
$$

where $L$ is the intensity of the stimulus pulse, a the initial concentration of the light sensitive substance, $x$ the quantity of the reaction product at time $t$, $\mathrm{k}_{1}$ and $\mathrm{k}_{2}$ velocity constants, and $\mathrm{m}$ a parametric constant. $\mathrm{k}_{2} \cdot \mathrm{x}^{\mathrm{n}}$ refers to that quantity of the reaction product which is either lost or used up in resynthesis.

Hecht further assumes that, when $t$ is small the rate of accumulation of $x$ can be presumed to be directly proportional to t. Equation 10 therefore can be expressed as

$$
\frac{x}{t}=k_{1} \cdot L \cdot(a-x)^{m}-k_{2} \cdot x^{n} .
$$

Rearrangement of this expression yields

$$
L \cdot t=\frac{x}{k_{1}(a-x)^{m}}+\frac{k_{2} \cdot x^{n} \cdot t}{k_{1}(a-x)^{m}}
$$

If an accumulation of a constant small amount of $x$ is required for threshold awareness, this expression can be written as

$$
\mathrm{L} \cdot \mathrm{t}=\mathrm{C}+\mathrm{D} \cdot \mathrm{t}
$$

where $\mathrm{C}$ and $\mathrm{D}$ are constants and are equal to $\mathrm{x} / \mathrm{k}_{1}(\mathrm{a}-\mathrm{x})^{\mathrm{m}}$ and $\mathrm{k}_{2} \cdot \mathrm{x}^{\mathrm{n}} / \mathrm{k}_{1}(\mathrm{a}-\mathrm{x})^{\mathrm{m}}$, respectively (see Bartlett, 1965).

Hecht argues that, in Equation 13, when t is small, $D \cdot t$ almost equals zero, and, therefore, $\mathrm{L} \cdot \mathrm{t}=\mathrm{C}$ for small values of $t$. This defines the reciprocity relation when $t$ is small. When, however, $t$ is large, $\mathrm{C} / \mathrm{t}$ 
in Equation 13 would be almost zero, and hence $\mathrm{L}$ would be approximately equal to $D$; it defines the constancy relation for large values of $t$.

Hecht's reasoning, however, is faulty. In the first instance, he is not justified in assuming that $\mathrm{dx} / \mathrm{dt}$, the velocity of chemical reaction, as defined by him, equals $x / t$. This could be true only when $x$, the accumulated chemical product, is directly proportional to t. Even when assuming that the relation will approximately hold when $t$ is small, Function 13 deduced under this assumption, then, could not be interpreted to define the outcomes for large values of $t$. Second, the rate of change in $L$ with increasing $t$ under Function 13 is inversely proportional to $t^{2}$ for all values of $t$; as such, there does not seem to to be any justification to interpret the rate of change in $L$ in one manner for small values of $t$ and in an altogether different manner for large values of $t$. The rate of change in $L$ certainly decreases with increasing $t$ under the Relation 13, but it does not imply that the character of the functional process materially changes from the reciprocity relation to constancy relation at some stage. The deductions made by Hecht under his formulations are, therefore, not at all convincing.

Graham and Kemp (1938) have attempted to extend Hecht's formulations to difference limen data to arrive at the reciprocity relation between DL and the duration of the comparison stimulus pulse for small durations. Their assumptions, also, are not very logical. For example, they have assumed the velocity of chemical reaction at time $t$ to be invariant with continued stimulation. This assumption violates the basic function 10 on which Hecht's formulations rest. Their assumptions also fail to account for the constancy relation for large values of $t$.

\section{VALIDATION AGAINST ABSOLUTE LIMEN DATA}

The proposed time intensity relation for absolute limen, as defined through Equation 8, can be expressed as

$$
\mathrm{n} \cdot \log \mathrm{X}=\log \frac{\mathrm{e}^{\mathrm{rt}}}{\mathrm{e}^{\mathrm{rt}}-1}+\log \mathrm{C}
$$

or as

$$
\log X=A \cdot \log \frac{e^{r t}}{e^{r t}-1}+B
$$

where $A=1 / n$, and $B=(1 / n) \cdot \log C$.

Relation 15 is validated against the data of Graham and Margaria (1935) which are reproduced in Table 1. In fitting the function, the best fitting linear regres-
Table 1

Observed $\log$ Xt Values for Four Different Areas of Retinal Stimulation Against the Values of $t$ Ranging

\begin{tabular}{|c|c|c|c|c|}
\hline \multirow{3}{*}{$\begin{array}{c}\text { Duration } \\
\mathbf{t}\end{array}$} & \multicolumn{4}{|c|}{ Log Xt Values } \\
\hline & \multicolumn{4}{|c|}{ Area } \\
\hline & $2^{\prime}$ & $16^{\prime}$ & $1^{\circ}$ & $3^{\circ}$ \\
\hline .00031 & & 5.97 & 6.75 & 6.25 \\
\hline .00063 & & 5.98 & 6.77 & 6.25 \\
\hline .001 & 3.29 & & & \\
\hline .00125 & & 5.97 & 6.78 & 6.27 \\
\hline .002 & 3.28 & & & \\
\hline .0025 & & 5.98 & 6.77 & 6.35 \\
\hline .004 & 3.28 & & & \\
\hline .005 & & 5.99 & 6.81 & 6.34 \\
\hline .008 & 3.29 & & & \\
\hline .01 & & 5.98 & 6.83 & 6.41 \\
\hline .016 & 3.30 & & & \\
\hline .02 & & 5.99 & 6.87 & 6.45 \\
\hline .032 & 3.30 & & & \\
\hline $.04^{\circ}$ & & 4.02 & 5.05 & 6.60 \\
\hline .064 & 3.28 & & & \\
\hline .08 & & 4.11 & 5.18 & 6.70 \\
\hline .128 & 3.40 & & & \\
\hline .16 & & 4.23 & 5.26 & 6.85 \\
\hline .256 & 3.59 & & & \\
\hline .32 & & 4.40 & 5.46 & 6.99 \\
\hline .50 & 3.87 & & & \\
\hline .64 & & 4.68 & 5.63 & 5.17 \\
\hline
\end{tabular}
From .00031 to $.64 \mathrm{sec}$

Note-Data are taken from Graham and Margaria (1935); reproduced by courtesy of the American Journal of Physiology.

sion equation is defined by choosing an appropriate value of the parameter $r$ which maximized the correlation between the variables $\log \mathrm{X}$ and $\log \mathrm{ert}^{\mathrm{rt}} /\left(\mathrm{e}^{\mathrm{rt}}-1\right)$. Table 2 presents the observed and estimated values of $\log \mathrm{X}$ for four sets of data with different areas of retinal stimulation. Correlations between the observed and estimated sets of values of $\log X$ are found to be of the order of .9995 and .9999 for the two smaller areas of retinal stimulation and of .9978 and .9986 for the two larger areas of retinal stimulation. This shows a fairly good fit of the proposed function to observed data. A comparatively poorer fit of the function with the observations obtained with larger areas of stimulation is in accord with our expectations. When larger areas of retinal stimulation are involved, it will be wrong to assume that the values of the parametric constants $r$ and $n$ would be identical for the total set of receptor cells. The proposed function, then, could not reflect the summated effects. The best fitting values of the parameters in that case could only reflect the central tendency about which there would be greater variation as the area of retinal stimulation increases. This would naturally increase the error component in fitting the proposed function.

The data include observations for values of $t$ dispersed from .00031 to $.64 \mathrm{sec}$. This covers the range of $t$ values falling under both the reciprocity rela- 
Table 2

Observed (O) and Estimated (E) Values of $\log X$

\begin{tabular}{|c|c|c|c|c|c|c|c|c|}
\hline \multirow[b]{3}{*}{ Duration } & \multicolumn{2}{|c|}{$2^{\prime}$ Area } & \multicolumn{2}{|c|}{$16^{\prime}$ Area } & \multicolumn{2}{|c|}{$1^{\circ}$ Area } & \multicolumn{2}{|c|}{$3^{\circ}$ Area } \\
\hline & \multicolumn{2}{|c|}{ Log X Values } & \multicolumn{2}{|c|}{ Log X Values } & \multicolumn{2}{|c|}{ Log X Values } & \multicolumn{2}{|c|}{ Log X Values } \\
\hline & 0 & $\mathbf{E}$ & 0 & E & $\underline{0}$ & $\mathrm{E}$ & 0 & E \\
\hline \multirow{2}{*}{\multicolumn{9}{|c|}{$\begin{array}{l}.00063 \\
001\end{array}$}} \\
\hline & & & & & & & & \\
\hline \multicolumn{9}{|l|}{$\begin{array}{l}.001 \\
.00125\end{array}$} \\
\hline \multicolumn{9}{|l|}{$\begin{array}{l}.002 \\
.0025\end{array}$} \\
\hline \multicolumn{9}{|l|}{$\begin{array}{l}.004 \\
.005\end{array}$} \\
\hline \multicolumn{9}{|l|}{$\begin{array}{l}.005 \\
.008\end{array}$} \\
\hline \multicolumn{9}{|c|}{-3.108} \\
\hline \multicolumn{9}{|c|}{-.904} \\
\hline $\begin{array}{l}.02 \\
.032\end{array}$ & -1.205 & \multicolumn{3}{|l|}{-1.223} & -3.431 & -3.360 & -3.851 & -3.797 \\
\hline \multicolumn{9}{|l|}{$\begin{array}{l}.04 \\
.064\end{array}$} \\
\hline & -1.525 & -1.480 & -2.793 & -2.806 & -3.723 & -3.811 & -4.203 & -4.241 \\
\hline & -1.707 & -1.685 & & & & & & \\
\hline \multirow{3}{*}{$\begin{array}{l}.160 \\
.256 \\
.32 \\
.50 \\
.64\end{array}$} & & & -2.974 & -2.989 & -3.944 & -3.978 & -4.354 & -4.417 \\
\hline & -1.818 & -1.811 & -3.105 & -3.095 & -4.045 & -4.077 & -4.515 & -4.535 \\
\hline & -1.829 & -1.854 & -3.126 & -3.126 & -4.176 & -4.110 & -4.636 & -4.585 \\
\hline \multirow{5}{*}{$\begin{array}{l}\mathrm{SE}^{2} \\
\text { Correlation } \\
\text { Constant I } \\
\text { Constant A } \\
\text { Constant B }\end{array}$} & \multirow{2}{*}{\multicolumn{2}{|c|}{$\begin{array}{l}.00054 \\
.9995\end{array}$}} & \multirow{2}{*}{\multicolumn{2}{|c|}{$\begin{array}{l}.00011 \\
.9999\end{array}$}} & \multirow{2}{*}{\multicolumn{2}{|c|}{.00265}} & \multicolumn{2}{|c|}{.00163} \\
\hline & & & & & & & & \\
\hline & \multicolumn{2}{|c|}{9.0} & \multicolumn{2}{|c|}{8.1} & \multicolumn{2}{|c|}{7.6} & \multicolumn{2}{|c|}{6.0} \\
\hline & \multicolumn{2}{|c|}{1.057008} & \multicolumn{2}{|c|}{1.00446} & \multicolumn{2}{|c|}{.88519} & & \\
\hline & -1 . & & -3 & & & & & \\
\hline
\end{tabular}

Note-Observed values of $\log X$ from the data of Graham and Margaria (1935).

Table 3

DI/I as a Function of Intensity and Duration

\begin{tabular}{|c|c|c|c|c|c|c|c|}
\hline \multirow[b]{3}{*}{$\log I^{*}$} & \multicolumn{7}{|c|}{$\log D I / I$} \\
\hline & \multicolumn{7}{|c|}{ Duration in Seconds } \\
\hline & .002 & .005 & .013 & .030 & .080 & .200 & .500 \\
\hline 2.27 & & -.65 & -.98 & -1.33 & -1.44 & -1.30 & -1.35 \\
\hline 1.67 & -.22 & -.65 & -.99 & -1.27 & -1.34 & -1.20 & -1.40 \\
\hline 1.27 & -.22 & -.60 & -.90 & -1.20 & -1.40 & -1.22 & -1.33 \\
\hline .67 & -.23 & -.53 & -.93 & -1.23 & -1.37 & -1.33 & -1.30 \\
\hline .27 & -.13 & -.53 & -.85 & -1.09 & -1.33 & -1.37 & -1.34 \\
\hline-.33 & .08 & -.33 & -.69 & -.94 & -1.26 & -1.27 & -1.25 \\
\hline-.73 & .37 & 0.00 & -.62 & -.81 & -1.19 & -1.23 & -1.11 \\
\hline-1.33 & .65 & .21 & -.23 & -.57 & -.03 & -.99 & -.92 \\
\hline-1.73 & .89 & .45 & .01 & -.36 & -.92 & -.92 & -.83 \\
\hline-2.33 & 1.35 & .89 & .53 & .16 & -.26 & -.40 & -.34 \\
\hline-2.73 & 1.68 & 1.23 & .87 & .51 & .01 & -.08 & -.07 \\
\hline
\end{tabular}

tion and the constancy relation. The significant feature demonstrated by the proposed function is that it shows an equally good fit for the entire range of $t$ values, as anticipated.

The best fitting values of the parametric constants also seem to be quite meaningful. The value of parameter $r$ is found to decrease with increasing area of retinal stimulation. It signifies that the negative opposing process conceived under the model becomes weaker as the area of retinal stimulation increases. This, in a way, seems to account for summation effects in the visual sense. The best fitting value of $\log C$ in Equation 15 also decreases with increasing area of retinal stimulation. It is in congruity with lower threshold intensities as the area of retinal stimulation increases.

In view of the above findings, it is reasonable to infer that the proposed function has the potential of systematizing the time-intensity relation for absolute thresholds in the visual sense more intelligibly than is possible under the currently accepted dichotomy. 
Table 4

Observed and Estimated Values of DX Under the Relation $(X+D X)^{n} / X^{n}=A \cdot e^{r t} /\left(e^{r t}-1\right)+B$ with $t$ as Variant

\begin{tabular}{|c|c|c|c|c|c|c|c|c|c|c|c|c|}
\hline & .002 & .005 & .013 & .03 & .08 & .2 & .5 & $\mathrm{n}$ & I & $\mathrm{C}^{*}$ & A & $\mathrm{B}$ \\
\hline & \multicolumn{12}{|c|}{$\log X=1.67 \mathrm{~mL}$} \\
\hline \multirow[t]{2}{*}{$\begin{array}{l}\text { Observed DX } \\
\text { Estimated DX }\end{array}$} & $\begin{array}{l}28.1838 \\
28.0799\end{array}$ & $\begin{array}{l}10.4713 \\
10.8747\end{array}$ & $\begin{array}{l}4.8978 \\
4.4128\end{array}$ & $\begin{array}{l}2.5119 \\
2.7719\end{array}$ & $\begin{array}{l}2.9512 \\
2.5632\end{array}$ & $\begin{array}{l}2.9512 \\
2.5626\end{array}$ & $\begin{array}{l}1.8621 \\
2.5626\end{array}$ & .85 & 115 & .9988 & .115070 & .931311 \\
\hline & \multicolumn{12}{|c|}{$\log X=1.27 \mathrm{~mL}$} \\
\hline \multirow[t]{2}{*}{$\begin{array}{l}\text { Observed DX } \\
\text { Estimated DX }\end{array}$} & $\begin{array}{l}11.2202 \\
11.2101\end{array}$ & $\begin{array}{l}4.6774 \\
4.7422\end{array}$ & $\begin{array}{l}2.3442 \\
2.1846\end{array}$ & $\begin{array}{l}1.1749 \\
1.3364\end{array}$ & $\begin{array}{l}1.1220 \\
1.0370\end{array}$ & $\begin{array}{l}1.1220 \\
1.0110\end{array}$ & $\begin{array}{r}.8710 \\
1.0109\end{array}$ & .85 & 45 & .9994 & .042070 & 1.003892 \\
\hline & \multicolumn{12}{|c|}{$\log X=.67 \mathrm{~mL}$} \\
\hline \multirow[t]{2}{*}{$\begin{array}{l}\text { Observed DX } \\
\text { Estimated DX }\end{array}$} & $\begin{array}{l}2.7542 \\
2.8098\end{array}$ & $\begin{array}{l}1.3804 \\
1.2190\end{array}$ & $\begin{array}{l}.5495 \\
.5783\end{array}$ & $\begin{array}{l}.2754 \\
.3538\end{array}$ & $\begin{array}{l}.2188 \\
.2486\end{array}$ & $\begin{array}{l}.2188 \\
.2147\end{array}$ & $\begin{array}{l}.2344 \\
.2070\end{array}$ & .9 & 10 & .9965 & .009848 & 1.029828 \\
\hline & \multicolumn{12}{|c|}{$\log X=.27 \mathrm{~mL}$} \\
\hline \multirow[t]{2}{*}{$\begin{array}{l}\text { Observed DX } \\
\text { Estimated DX }\end{array}$} & $\begin{array}{l}1.3804 \\
1.3776\end{array}$ & $\begin{array}{l}.5495 \\
.5620\end{array}$ & $\begin{array}{l}.2630 \\
.2492\end{array}$ & $\begin{array}{l}.1514 \\
.1427\end{array}$ & $\begin{array}{l}.0794 \\
.0956\end{array}$ & $\begin{array}{l}.0794 \\
.0841\end{array}$ & $\begin{array}{l}.0912 \\
.0832\end{array}$ & .70 & 20 & 9997 & .018056 & 1.013028 \\
\hline & \multicolumn{12}{|c|}{$\log X=-.33 \mathrm{~mL}$} \\
\hline \multirow[t]{2}{*}{$\begin{array}{l}\text { Observed DX } \\
\text { Estimated DX }\end{array}$} & $\begin{array}{l}.5623 \\
.5617\end{array}$ & $\begin{array}{l}.2188 \\
.2217\end{array}$ & $\begin{array}{l}.0955 \\
.0929\end{array}$ & $\begin{array}{l}.0537 \\
.0494\end{array}$ & $\begin{array}{l}.0251 \\
.0303\end{array}$ & $\begin{array}{l}.0251 \\
.0256\end{array}$ & $\begin{array}{l}.0263 \\
.0252\end{array}$ & .75 & 20 & .9998 & .031291 & 1.008914 \\
\hline & \multicolumn{12}{|c|}{$\log X=-.73 \mathrm{~mL}$} \\
\hline \multirow[t]{2}{*}{$\begin{array}{l}\text { Observed DX } \\
\text { Estimated DX }\end{array}$} & $\begin{array}{l}.4365 \\
.4361\end{array}$ & $\begin{array}{l}.1514 \\
.1512\end{array}$ & $\begin{array}{l}.0447 \\
.0502\end{array}$ & $\begin{array}{l}.0288 \\
.0207\end{array}$ & $\begin{array}{l}.0110 \\
.0133\end{array}$ & $\begin{array}{l}.0110 \\
.0131\end{array}$ & $\begin{array}{l}.0145 \\
.0131\end{array}$ & .75 & 70 & 9996 & .213306 & .839135 \\
\hline & \multicolumn{12}{|c|}{$\log X=-1.33 \mathrm{~mL}$} \\
\hline \multirow[t]{2}{*}{$\begin{array}{l}\text { Observed DX } \\
\text { Estimated DX }\end{array}$} & $\begin{array}{l}.2089 \\
.2084\end{array}$ & $\begin{array}{l}.0759 \\
.0769\end{array}$ & $\begin{array}{l}.0275 \\
.0280\end{array}$ & $\begin{array}{l}.0126 \\
.0121\end{array}$ & $\begin{array}{l}.0048 \\
.0056\end{array}$ & $\begin{array}{l}.0048 \\
.0046\end{array}$ & $\begin{array}{l}.0056 \\
.0046\end{array}$ & .85 & 30 & 9999 & .194677 & .887355 \\
\hline & \multicolumn{12}{|c|}{$\log X=-1.73 \mathrm{~mL}$} \\
\hline \multirow[t]{2}{*}{$\begin{array}{l}\text { Observed DX } \\
\text { Estimated DX }\end{array}$} & $\begin{array}{l}.1445 \\
.1446\end{array}$ & $\begin{array}{l}.0525 \\
.0525\end{array}$ & $\begin{array}{l}.0191 \\
.0189\end{array}$ & $\begin{array}{l}.0081 \\
.0080\end{array}$ & $\begin{array}{l}.0022 \\
.0033\end{array}$ & $\begin{array}{l}.0022 \\
.0022\end{array}$ & $\begin{array}{l}.0028 \\
.0021\end{array}$ & .85 & 20 & 9999 & .213612 & .880164 \\
\hline & \multicolumn{12}{|c|}{$\log X=-2.33 \mathrm{~mL}$} \\
\hline \multirow[t]{2}{*}{$\begin{array}{l}\text { Observed DX } \\
\text { Estimated DX }\end{array}$} & $\begin{array}{l}.1047 \\
.1043\end{array}$ & $\begin{array}{l}.0363 \\
.0380\end{array}$ & $\begin{array}{l}.0158 \\
.0142\end{array}$ & $\begin{array}{l}.0068 \\
.0066\end{array}$ & $\begin{array}{l}.0026 \\
.0033\end{array}$ & $\begin{array}{l}.0019 \\
.0021\end{array}$ & $\begin{array}{l}.0021 \\
.0017\end{array}$ & .85 & 5 & .9995 & .132925 & 1.163898 \\
\hline & \multicolumn{12}{|c|}{$\log X=-2.73 \mathrm{~mL}$} \\
\hline $\begin{array}{l}\text { Observed DX } \\
\text { Estimated DX }\end{array}$ & $\begin{array}{l}.0891 \\
.0889\end{array}$ & $\begin{array}{l}.0316 \\
.0335\end{array}$ & $\begin{array}{l}.0138 \\
.0127\end{array}$ & $\begin{array}{l}.0060 \\
.0059\end{array}$ & $\begin{array}{l}.0019 \\
.0029\end{array}$ & $\begin{array}{l}.0015 \\
.0019\end{array}$ & $\begin{array}{l}.0016 \\
.0015\end{array}$ & .9 & 5 & .9995 & .315519 & 1.262674 \\
\hline
\end{tabular}

Note-Observed values of $D X$ from the data of Graham and Kemp (1938).

${ }^{*} C=$ Correlation between $(X+D X)^{n / X^{n}}$ and $e^{r t} /\left(e^{r t}-1\right)$.

\section{VALIDATION AGAINST DIFFERENCE LIMEN DATA}

The validity of Function 7 defining the relation between DX and $t$ is examined against the data of Graham and Kemp (1938). They present the variations in jnds for seven exposure durations from 2 to $500 \mathrm{msec}$ for 11 adapting luminances in the range from -2.75 to $2.27 \log \mathrm{mL}$. The results of their experiment are reproduced in Table 3 . The first set of observations for the $\log$ intensity of $2.27 \mathrm{~mL}$ is not included in the computations, since it offers only six values of DX as against seven in others.

Table 4 presents the observed and estimated magnitudes of DX for the 10 sets of data.

Since no direct method could be employed to determine the best fitting values of the parametric constants $r$ and $n$ in the proposed function, their values are based on a rough estimate such that they would define fairly satisfactory correlations between the functions $(X+D X)^{n} / X^{n}$ and $e^{r t} /\left(e^{r t}-1\right)$. There is, therefore, a further scope for improvement in achieving a better fit with more rigorously defined values of $r$ and $n$ in each set of the observations.

In fitting the proposed function to observed data, the correlations between the functions $(X+D X)^{n} / X^{n}$ and $\mathrm{e}^{\mathrm{rt}} /\left(\mathrm{e}^{\mathrm{rt}}-1\right)$, with appropriate choice of values of $r$ and $n$, are found to be of the order of .999 for each set of observations. This represents a fairly good fit of the proposed function to observed data.

The proposed function is not so meticulously defined that it may be able to cope with the unexpected increments in DX for the extreme value of $t$, i.e., for $\mathrm{t}=.5 \mathrm{sec}$. This departure in $\mathrm{DX}$ values for large stimulus durations away from the general trend could perhaps be explained under a more rigorously defined function which would give a due weighting to the appreciable changes in adaptation level with continued stimulation (Helson, 1947, 1948).

Table 5 presents estimated magnitudes of DX 
Table 5

Estimated Values of DX Under the Relation $(X+D X)^{n} / X^{n}=A \cdot e^{r t} /\left(e^{r t}-1\right)+B$ Without the Inclusion of Observations for $500 \mathrm{msec}$

\begin{tabular}{|c|c|c|c|c|c|c|c|c|c|c|c|}
\hline & \multicolumn{6}{|c|}{ Duration of the Comparison Stimulus Pulse in Seconds } & \multirow[b]{2}{*}{$\mathbf{n}$} & \multirow[b]{2}{*}{$\mathbf{r}$} & \multirow[b]{2}{*}{$\mathrm{C}^{*}$} & \multirow[b]{2}{*}{ A } & \multirow[b]{2}{*}{ B } \\
\hline & .002 & .005 & .013 & .030 & .080 & .200 & & & & & \\
\hline & \multicolumn{11}{|c|}{$\log X=1.67 \mathrm{~mL}$} \\
\hline \multirow[t]{2}{*}{$\begin{array}{l}\text { Observed DX } \\
\text { Estimated DX }\end{array}$} & $\begin{array}{l}28.1838 \\
28.1226\end{array}$ & $\begin{array}{l}10.4713 \\
10.7070\end{array}$ & $\begin{array}{l}4.8978 \\
4.5324\end{array}$ & $\begin{array}{l}2.5119 \\
2.9974\end{array}$ & $\begin{array}{l}2.9512 \\
2.8032\end{array}$ & $\begin{array}{l}2.9512 \\
2.8026\end{array}$ & .55 & 115 & .9994 & .068019 & .964505 \\
\hline & \multicolumn{11}{|c|}{$\log X=1.27 \mathrm{~mL}$} \\
\hline \multirow[t]{2}{*}{$\begin{array}{l}\text { Observed DX } \\
\text { Estimated DX }\end{array}$} & $\begin{array}{l}11.2202 \\
11.2071\end{array}$ & $\begin{array}{l}4.6774 \\
4.7494\end{array}$ & $\begin{array}{l}2.3442 \\
2.1840\end{array}$ & $\begin{array}{l}1.1749 \\
1.3516\end{array}$ & $\begin{array}{l}1.1220 \\
1.0919\end{array}$ & $\begin{array}{l}1.1220 \\
1.0776\end{array}$ & .9 & 55 & .9996 & .055372 & .996563 \\
\hline & \multicolumn{11}{|c|}{$\log X=.67 \mathrm{~mL}$} \\
\hline \multirow[t]{2}{*}{$\begin{array}{l}\text { Observed DX } \\
\text { Estimated DX }\end{array}$} & $\begin{array}{l}2.7542 \\
2.8704\end{array}$ & $\begin{array}{l}1.3804 \\
1.2248\end{array}$ & $\begin{array}{l}.5495 \\
.5758\end{array}$ & $\begin{array}{l}.2754 \\
.3465\end{array}$ & $\begin{array}{l}.2188 \\
.2388\end{array}$ & $\begin{array}{l}.2188 \\
.2040\end{array}$ & 1.0 & 10 & .9967 & .01128 & 1.030566 \\
\hline & \multicolumn{11}{|c|}{$\log X=.27 \mathrm{~mL}$} \\
\hline \multirow[t]{2}{*}{$\begin{array}{l}\text { Observed DX } \\
\text { Estimated DX }\end{array}$} & $\begin{array}{l}1.3804 \\
1.3784\end{array}$ & $\begin{array}{l}.5405 \\
.5602\end{array}$ & $\begin{array}{l}.2630 \\
.2494\end{array}$ & $\begin{array}{l}.1514 \\
.1432\end{array}$ & $\begin{array}{l}.0794 \\
.0940\end{array}$ & $\begin{array}{l}.0794 \\
.0782\end{array}$ & .65 & 10 & .9997 & .008236 & 1.017558 \\
\hline & \multicolumn{11}{|c|}{$\log X=-.35 \mathrm{~mL}$} \\
\hline \multirow[t]{2}{*}{$\begin{array}{l}\text { Observed DX } \\
\text { Estimated DX }\end{array}$} & $\begin{array}{l}.56234 \\
.56198\end{array}$ & $\begin{array}{l}.21878 \\
.22074\end{array}$ & $\begin{array}{l}.09550 \\
.09331\end{array}$ & $\begin{array}{l}.05370 \\
.05022\end{array}$ & $\begin{array}{l}.02512 \\
.03032\end{array}$ & $\begin{array}{l}.02512 \\
.02395\end{array}$ & .7 & 10 & .9999 & .014223 & 1.019123 \\
\hline & \multicolumn{11}{|c|}{$\log X=-.73 \mathrm{~mL}$} \\
\hline \multirow[t]{2}{*}{ Estimated DX } & $\begin{array}{l}.43652 \\
.43591\end{array}$ & $\begin{array}{l}.15136 \\
.15156\end{array}$ & $\begin{array}{l}.04467 \\
.05059\end{array}$ & $\begin{array}{l}.02884 \\
.02053\end{array}$ & $\begin{array}{l}.01097 \\
.01250\end{array}$ & $\begin{array}{l}.01097 \\
.01222\end{array}$ & .75 & 65 & .9995 & .197462 & .851383 \\
\hline & \multicolumn{11}{|c|}{$\log X=-1.33 \mathrm{~mL}$} \\
\hline \multirow[t]{2}{*}{ Estimated DX } & $\begin{array}{l}.20893 \\
.20888\end{array}$ & $\begin{array}{l}.07586 \\
.07585\end{array}$ & $\begin{array}{l}.02754 \\
.02789\end{array}$ & $\begin{array}{l}.01259 \\
.01231\end{array}$ & $\begin{array}{l}.00479 \\
.00559\end{array}$ & $\begin{array}{l}.00479 \\
.00398\end{array}$ & .8 & 20 & .99997 & .115343 & .94994 \\
\hline & \multicolumn{11}{|c|}{$\log X=-1.73 \mathrm{~mL}$} \\
\hline $\begin{array}{l}\text { Observed DX } \\
\text { Estimated DX }\end{array}$ & $\begin{array}{l}.14454 \\
.14455\end{array}$ & $\begin{array}{l}.05248 \\
.05255\end{array}$ & $\begin{array}{l}.01906 \\
.01888\end{array}$ & $\begin{array}{l}.00813 \\
.0079\end{array}$ & $\begin{array}{l}.00224 \\
.00307\end{array}$ & $\begin{array}{l}.00224 \\
.00172\end{array}$ & .85 & 15 & .99995 & .160139 & .909397 \\
\hline & $\begin{array}{l}.10471 \\
.10435\end{array}$ & $\begin{array}{l}.03631 \\
.03788\end{array}$ & $\begin{array}{l}.01585 \\
.01406\end{array}$ & $\begin{array}{l}.00676 \\
.00648\end{array}$ & $\begin{array}{c}\log X= \\
.00257 \\
.00315\end{array}$ & $\begin{array}{r}2.33 \mathrm{~mL} \\
.00186 \\
.00212\end{array}$ & .85 & 10 & .9995 & .266708 & 1.065288 \\
\hline Estimated DX & \multicolumn{11}{|c|}{$\log X=-2.73 \mathrm{~mL}$} \\
\hline $\begin{array}{l}\text { Observed DX } \\
\text { Estimated DX }\end{array}$ & $\begin{array}{l}.08912 \\
.08875\end{array}$ & $\begin{array}{l}.03162 \\
.03312\end{array}$ & $\begin{array}{l}.01380 \\
.01235\end{array}$ & $\begin{array}{l}.00603 \\
.00558\end{array}$ & $\begin{array}{l}.00191 \\
.00258\end{array}$ & $\begin{array}{l}.00155 \\
.00165\end{array}$ & .9 & 10 & .9995 & .632828 & 1.036266 \\
\hline
\end{tabular}

Note-Observed values of DX from the data of Graham and Kemp (1938).

${ }^{*} C=$ Correlations between the observed and estimated values of the function $(X+D X)^{n / X^{n}}$.

when the last observation corresponding to $t=.5 \mathrm{sec}$ in the data is not included in computations. When the last observation is left out, the error component in the estimated magnitudes of DX is very much reduced, and a better fit under a theoretically defined function could not be anticipated. What is more important, there is a reasonable consistency in the estimates of parametric values of $r$ and $n$ for different sets of observations. In fact, choosing the same set of values of $r$ and $n$, viz, $r=30$ and $n=.8$, yields correlations in the range of .9957 to .9999 between $(\mathrm{X}+\mathrm{DX})^{\mathrm{n}} / \mathrm{X}^{\mathrm{n}}$ and $\mathrm{e}^{\mathrm{rt}} /\left(\mathrm{e}^{\mathrm{rt}}-1\right)$ for different luminances. The estimated values of DX under a uniform set of values of $r$ and $n$ for different sets of data are presented in Table 6. The fit of the proposed function, even under a uniform set of values of $r$ and $n$, to the entire set of data is fairly satisfactory. It shows that the conformity of the proposed function to a small number of observations in each set of data is not simply a matter of accident; it seems, rather, to reflect a sound theoretical proposition which is capable of defining the outcomes satisfactorily in the entire range of $t$ values for different stimulus intensities.

\section{DISCUSSION}

This paper clearly demonstrates that the functional relations proposed here between $\mathrm{C}$ and $\mathrm{t}$ for the absolute limen, and DX and $t$ for difference limen, show a much better fit with observed data than is possible under the reciprocity and constancy relations at different ranges of $t$ values. The proposed function, in addition, is equally capable of accounting for the outcomes in the intermediary range of $t$ values for which no suitable empirically defined function exists in current psychophysics. What is more important, the proposed functions are deduced 
Table 6

Estimated Values of $D X$ with $r=30$ and $n=.8$ for All Sets of Data, Under the Relation $(X+D X)^{n} / X^{n}=A \cdot e^{r t} /\left(e^{r t}-1\right)+B$

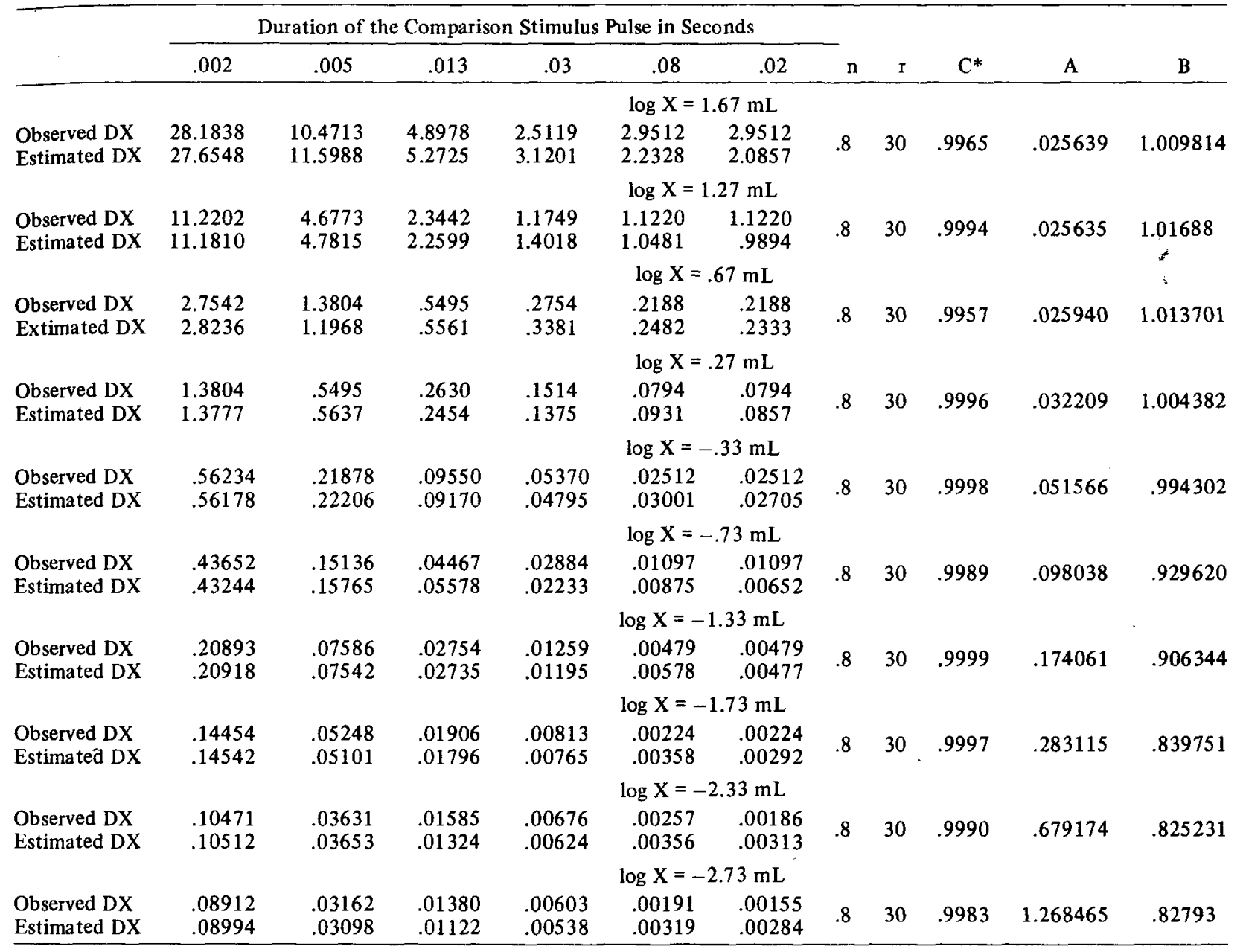

Note-Observed values of $D X$ from the data of Graham and Kemp (1938).

${ }^{*} C=$ Correlations between the observed and estimated values of the function $(X+D X)^{n} / X^{n}$.

under some very simple and rational assumptions characterizing the basic features of intervening neural excitations. Thus, they have a sound theoretical base unlike the empirically defined reciprocity and constancy relations.

The theoretical and empirical validity of the proposed formulations, as demonstrated in this paper, is meaningful. It draws our attention to the shortcomings of current theories in psychophysics, and substantiates the possibility of interpreting diverse psychophysical phenomena under a single unified set of principles.

\section{REFERENCES}

Bartlett, N. R. Threshold as dependent on some energy relations and characteristics of the subject. In C. H. Graham (Ed.), Vision and visual perception. New York: Wiley, 1965.

Blondel, A., \& REY, J. Sur la perception des lumières brèves à la limite de leur portée. Journal de Physiologie, $1911,1,530-550$.
DAvY, E. The intensity-time relation for multiple flashes of light in the peripheral retina. Journal of the Optical Society of America, 1952, 42, 937-941.

GrahaM, C. H., \& KEMP, E. H. Brightness discrimination as a function of the duration of the increment in intensity. Journal of General Physiology, 1938, 21, 635-650.

Graham, C. H., \& Margaria, R. Area and the intensity-time relation in the peripheral retina. American Journal of Physiology, 1935, 113, 299-305.

HARTLINE, H. K. Intensity and duration in the excitation of single photoreceptor units. Journal of Cell and Comparative Physiology, 1934, 5, 229-247.

Hartline, H. K. The response of single optic nerve fibers, of the vertebrate eye to illumination of the retina. American Journal of Physiology, 1938, 121, 400-415.

Hecht, S. Vision II. The nature of the photoreceptor process. In C. Murchison (Ed.), A handbook of general experimental psychology. Worcester, Mass: Clark University Press, 1934.

Helson, H. Adaptation level as frame of reference for predicting of psychophysical data. American Journal of Psychology, 1947, 60, 1-29.

Hecson, H. Adaptation level as a basis for quantitative theory of frames of reference. Psychological Review, 1948, 55, 297-313.

HERRICK, R. M. Foveal luminance discrimination as a function of 
the duration of the decrement or increment in luminance. Journal of Comparative Physiological Psychology, 1956, 49, 437-443.

KARN, H. W. Area and the intensity-time relationship in the fovea. Journal of General Psychology, 1936, 14, 360-369.

LoNG, G. E. The effect of duration of onset and cessation of light flash on the intensity-time relation in the peripheral retina. Journal of the Optical Society of America, 1951, 41, 743-747.

Mote, F. A. Visual sensitivity. Annual Review of Psychology, $1967,18,41-64$.
Rouse, R. O. Color and the intensity-time relation. Journal of the Optical Society of America, 1952, 42, 626-630.

TAYAL, O. P. Intervening neural activity in visual perception: A hypothetical construct. Journal of General Psychology, 1965, 72, 199-219.

(Received for publication May 1977; revision accepted September 19, 1977.) 